\title{
THE EXPRESSION OF THE FUTURE*
}

\author{
Charles C. Fries \\ UNIVERSITY OF MICHIGAN
}

The concept of time in relation to action finds expression in the verbal forms of a great many, although not all, languages. 'In English we have made up our minds that all action must be conceived of in reference to three standard times', 1 - the present, the past, and the future. Of these three, the devices for the expression of the future-their origin, development, and present use-receive from our grammarians the least satisfactory treatment.

The common school grammars of modern English usually give as the one means of indicating future time the combination of shall and will with the infinitive form of the verb and name it the future tense. ${ }^{2}$ Some give two forms of the future tense: one for simple futurity and another for determination. ${ }^{3}$ As a matter of fact, however, the use of the auxiliaries shall and will with the infinitive is but one of several important methods of expressing the future and certainly does not deserve the title 'the future tense'. Some other combinations having a claim to be included in an English future tense are:

(a) the verb to be + prepositional infinitive. (He is to go with the committee.)

(b) the verb to be-about + prepositional infinitive. (The man is about to dive from the bridge.)

(c) the verb to be + going + prepositional infinitive. (They are going to go by automobile.)

Then too, the present form of the verb frequently refers to future time both in subordinate clauses and in independent sentences when some other word than the verb, or the context in general, indicates the time idea. (If it rains, I cannot go.) (He returns from his trip tomorrow.)

On the other hand, the use of shall and will to express determination (sometimes called 'the emphatic future', or 'the colored future', or 'the

${ }^{1}$ E. Sapir, Language 104.

'See, for example, Kittredge and Arnold, The Mother Tongue (1901), 2. 240.

'See, for example, Scott and Buck. A Brief English Grammar, 125 (190').

*|Editor's Note: Language Learning expresses its gratitude to the Linguistic Society of America, and especially to Bernard Bloch, Editor of Language, for permission to reprint this article, which first appeared in Lunguage, Vol. III, No. 2, pp. 87-95.] 
modal future') is no more entitled to be included in the name 'future tense' than many other combinations of verbs which, because of their meaning, look to the future for fulfillment:
I desire to go.
I mean to go.
I want to go.
I have to go.
I need to go.
I may go.
I intend to go.
I can go.
I expect to go.
I must go.
I ought to go.
I might go.
I've got to go.
I should go.

In English, then, we have a variety of devices that express actions conceived of in future time. Most of them, like desire, or expect, or intend, joined with the prepositional infinitive, carry full word meanings and refer to the future because of the nature of these meanings. Others, like may, or the stressed shall, with the simple infinitive, or have with the prepositional infinitive possess a clearly distinct modal force. A few of these expressions seem at times to register mere tense meanings.

The usual statements of the grammarians concerning the origin, development, and present use of the devices to express the future make the following three points:

(1) Those words or inflectional forms were used for the future tense devices which naturally looked to the future for fulfillment. (Words of volition, purpose, obligation, necessity, and the modal inflections carrying the idea of possibility, as for example the present subjunctive. $)^{4}$

4 Fowler and Fowler, The King's English 134: 'But as commands and wishes are concerned mainly with the future, it was natural that a future tense auxiliary should be developed out of these two verbs.'

G. O. Curme, Journal of Eng. and Gmc. Phil. 13. 517: 'Originally will indicated a desire of the subject, while shall indicated that an act was due in accordance with the will of some other than the subject of the verb. The meaning of both of these verbs suggested their use to denote the idea of futurity.'

Maetzner, An English Grammar 2. 80: 'It is self-evident that shall and will may be referred to activities whose accomplishment belongs only to the future, and that both, by their nature, go essentially to a subject-matter which is not yet realized. The characteristic distinction of both consists in this, that shall points originally to the dependence or obligation imposed upon the subject by the determination of a foreign will, which may be taken as a command, as a moral obligation, or even as a physical necessity, whereas will denotes the subjective resolve and inclination of the agent.'

Brugmann, Comparative Grammar of the Indo-Germanic Languages 3.460 and 450 (1895). [Since there is but little essential difference between the views expressed in this earlier edition and those in the 1916 edition I have not used the later work 
because the statements made in the English version fitted my purpose better. The pertinent paragraphs of the 1916 edition are $2.3 . \$ 423.3 ; \S 705$.]

'The conjunctive has a simple future meaning in addition to that of wish (in which $I$ include deliberative and dubitative). Often these forms drop their other meanings in the separate languages, and have that of Future only, or chiefly. Then they are called future in the grammars, as are for instance Lat. erō, vìder $\delta . '$

'In Germanic the Idg. sio-future was lost, nor did this branch as others did, use certain conjunctive forms with future meaning only (as Lat. erō). For future events were used either perfect Present forms . . . . or the living conjunctive,

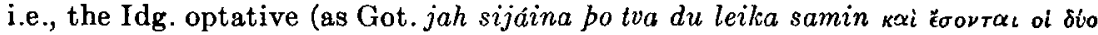
eis $\sigma \dot{\alpha} \rho \kappa \alpha \mu i \alpha \nu)$; or thirdly, periphrases with auxiliaries which naturally pointed to the future. But the use of these last with dependent infinitive (Got. haban, duginnan, skulan, OHG. scolon, muogan, wellen, wollen) did not lead to any fixed type in the old Germanic dialects, and each auxiliary bore its own proper meaning. Only phrases with sollen and wollen gained by degrees a simple future tense. Besides these periphrastic turns there was an idiom made up by werden (Got. wairpan, .OHG werdan) with the present participle which is found a few times, in

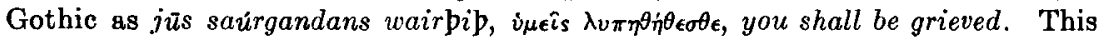
idiom in OHG little by little won its way till all others had disappeared, but in MHG. the participle was exchanged for the infinitive."

Otto Jespersen, Philosophy of Grammar 260, 261: 'It is easy to understand that expressions for times to come are less definite and less explicit in our languages than those for the past: we do not know so much about the future as about the past and are therefore obliged to talk about it in a more vague way. Many languages have no future tense proper or have even given up forms which they had once and replaced them by circuitous substitutes. I shall here give a survey of the principal ways in which languages have come to possess expressions for future time.

'(1) The present tense is used in a future sense. This is particularly easy when the sentence contains a precise indication of time in the form of a subjunct and when the distance in time from the present moment is not very great: . . . . The extent to which the present tense is thus used is different in different languages; the tendency is strongest with verbs denoting "go":

'(2) Volition. Both E will and Dan. vil to a certain degree retain traces of the original meaning of real volition, and therefore $\mathrm{E}$ will go cannot be given as a pure "future tense", though it approaches that function, as seen especially when it is applied to natural phenomena as it will certainly rain before night.

The future is expressed by volition also in Rumanian voiu canta "I will (shall) sing"; . . . . In Modern Greek the idea of volition seems to have been completely obliterated from the combinations with tha: . . . . tha, formerly thena, is derived from the third person thelei + na "that" from hina and has now become a pure temporal particle. (Note-In It. sta per partire "he is going to start" the notion of future seems to be due to per denoting an intention "in order to".)

'(3) Thought, intention, $\mathrm{ON}$ mun. This cannot easily be kept apart from volition.

'(4) Obligation. This is the original meaning of OE sceal, now shall and Dutch zal. . . . The meaning of obligation also clung at first to the Romanic form scribere-habeo "I have to write", which has now become a pure future tense, . . . . Under this head we may also place $\mathrm{E}$ is to as in "he is to start tomorrow". 
(2) The full word meanings of these words or the distinctly modal ideas of certain verb-forms gradually faded leaving the idea of future time alone to be registered. ${ }^{5}$

(3) With all the fading the primitive meanings have not entirely gone. In many cases they still 'glimmer through' coloring the ideas denoted by the auxiliaries or the inflectional forms and thus cause the complex character of the suggestions or connotations conveyed in most expressions of the future. ${ }^{6}$

'(5) Motion. Verbs meaning "go" and "come" are frequently used to indicate futurity, as in Fr. je vais écrire, used of the near future, E I am going to write. . . .

'(6) Possibility. E may frequently denotes a somewhat vague futurity: this may end in disaster. Here we may mention those cases in which an original present subjunctive has become a future tense, as Lat. scribam.

'(7) There are other ways in which expressions for futurity may develop . . . The Gr. future in -so (leipso, etc.) is said to have been originally a desiderative. A notional imperative necessarily has relation to the future time.'

\section{See also}

Jacob Grimm, Deutsche Grammalik (neuer vermehrter Abdrück besorgt durch Gustav Roethe und Edward Schroeder) 4. 206-19.

- I add but two examples to those given under the preceding note which touch this point also.

J. F. Royster and J. M. Steadman "The "Going-To" Future', The Manly Anniversary Studies in Language and Literature 402. "The track of the development of the going-to future seems easy to follow. It is reasonable to assume that it grew from the use of the progressive forms of go with the actual meaning of motion plus an infinitive of purpose or determination. The idea of actual motion to carry out the purpose weakened, and the combination came more and more to express merely purpose, intent, or determination. From a notional word, go falls into the state of an "empty" word.'

John Earle, The Philology of the English Tongue," Chapter V, §236. 'The word shall offers a good example of the movement from presentiveness to symbolism. When it flourished as a presentive word, it signified to owe. . . . . From this state it passed by slow and unperceived movements to that sense which is now most familiar to us, in which it is a verbal auxiliary, charging the verb with a sense fluctuating between the future tense and the imperative mood. There are intermediate uses of shall which belong neither to the presentive state when it signified "owe", nor to the symbolic state in which it is a mere imponderable auxiliary.' \$238. 'We see in the word will the graduated movement from the presentive to the symbolic state well displayed.'

- Maetzner, An English Grammar, 2. 82, 83, 81: 'The notion shall pervades, even in the modern tongue, a series of gradations, which are weakened down from the expression of a compulsion, subjectively or objectively determined, to the idea of expectation and of imminence.' 
Of these three statements the first can be accepted with but a brief comment. The evidence seems satisfactory that the devices for the expression of the future originated in those words and forms with meanings naturally looking to the future for fulfillment. One should, in passing, however, call attention to the fact that a considerable number of diverse languages have tried out the same set of devices for the future, although with differing results. The Germanic languages thus used haban, munan, skulan, wiljan, wairpan. ${ }^{7 \mathrm{a}}$ Late Latin and the Romance languages tried out velle, posse, debere, vadere, ire, venire, as well as habeo. ${ }^{\mathrm{b}}$ Late Greek used not only the subjunctives but also $\check{\epsilon} \chi \omega$ and $\theta \dot{\epsilon} \lambda \omega .^{70}$ Coptic used NA the primitive word meaning to go and also the preposition E meaning toward as devices for the future. ${ }^{7 \mathrm{~d}}$

:Will, appearing in the periphrastic future, appears no less in a manifold gradation of meanings, which gradually sink from the more decided expression of the will into weaker shades of the notion.' . . . .

'With the weakening of both the primitive meaning has not perished. The glimmering through of the latter gives to the modern tongue, on the one hand, occasion to avoid ambiguity, on the other, to express more delicate shades of thought, apart from the conventional distribution of the auxiliary verbs among the several persons.'

C. B. Bradley, 'Shall and Will, An Historical Study', Trans. of Am. Phil. Ass. 42. 15, 16, 17 (1911): 'Shall started in English with (1) the idea of pecuniary obligation or indebtedness . . . . I owe . . . . From this narrow beginning its scope was gradually extended to cover the field (2) of moral obligation in its specific sense of duty and propriety . . . From this use shall ranges upward through (3) the shall of superior authority in commands and laws . . . . to (4) the compulsion of force or of fate. . . . . Its meaning ranges also downward to (5) the shall which indicates merely that the action is determined upon, or scheduled to come off . . . . and forward (6) to that which is considered to be inevitable or certain, and so is vouched for by the speaker. . . . . At this stage it is clear that attention and interest are already shifted from the idea of circumstances which are now conditioning action, to the idea of the future event.'

'In polar antithesis to shall, will started with impulse from within, and meant (1) to desire, to wish, . . . . But desire may be heightened till it becomes resolve and will then means (2) to purpose, to intend, . . . . or it may be lowered to (3) to be willing, to consent to . . . The connotation here, it will be noted, is negative rather than positive. The proposed action encounters no opposition from the person named as agent, and so is in a fair way to take place. Exactly as we found in the case of shall when motive and circumstance sink in importance, interest and attention shift to the event.'

7. See Grimm, Deutsche Grammatik, 4. 206-19.

tb See Grandgent, An Introduction to Vulgar Latin, 56-8.

7c See Jannaris, Historical Greek Grammar 552-9 (Appendix IV, The Future Indicative Since Attic Times).

7d See Steindorff, Koptische Grammatik, $\$ \S 273,278,279,289,290$; and Stern, Koptische Grammatik 219-23. 
The process indicated in the second statement can also be accepted. These original meanings gradually fade and the words tend to become merely form or function words-auxiliaries of a future tense. The assumption, however, that this loss of full word meaning is the end of the process seems an invalid one and the statement that whatever connotations these expressions may still carry are 'glimmerings through' of previous meanings is plainly inadequate, for the three following reasons: ${ }^{8}$

(1) Although such an explanation would account for the meanings of desire or wish which might be suggested in a future phrase with will it does not account for the cases in which will with the second or third persons implies a compulsion to be brought upon the subject. ${ }^{9}$

(2) Although the explanation would account for any suggestions of compulsion which may attach to a future phrase with shall it does not account for the many cases in which the meanings of resolve or determination on the part of the subject attach to the future expression with shall. ${ }^{10}$

${ }^{8}$ I am repeating here two sentences, and in the footnotes several examples from my article, 'The Periphrastic Future with Shall and Will in Modern English', Pub. of Mdn. Lang. Ass. 40.963-1024.

9 Some examples of this use are the following:

'You will go to your room and stay there!' (The speaker's command.)

'A. He says that he has decided not to go to the court.

B. Well, he will go to the sourt even if we have to carry him.' (The subject is threatened with such pressure as will force him to act in direct opposition to his wish or resolve.)

In the following from Masefield's The Faithful, 1. 2. 51, the 'you will' expresses the speaker's not the subject's promise and determination.

'Kurano-Kira taught you the wrong ritual?

Asano-Yes.

Kurano-You will not go unavenged.'

The 'you'll', etc., in the following from Jane Shore, V., p. 208, line, 393, implies a threat of the speaker against the subject.

'Shore-Infamy on thy head!. . . .

Catesby-You'll answer this at full.-Away with 'em.'

${ }^{10}$ Some examples of this use are the following:

Masefield, The Faithful, I, 11, 11

'Lord Asano-This alters everything, I shall go at once to the Envoy's court and appeal against Kira.'

Cibber, Love's Last Shift, IV, 66

'. . . Damme! Sir, have a care! Don't give me the Jye, I shan't take it, Sir.' 
(3) Even if one insists that the 'glimmering through' of the purposeexpressing infinitive with going and about sufficiently accounts for the ideas of intention and determination which attach to the expression of the future in the following examples:

Pinero, The Second Mrs. Tanqueray, III, 62

'Paula-. . . My tongue runs away with me, I'm going to alter, I swear I am.'

Masefield, The Faithful, II, 1, 62

'Kurano-A re they going to kill me?

4th Ronin-They said they were going to make sure of you.'

'He has bought up two of our neighbors and is about to buy us up too.'

yet such an explanation could hardly account for the suggestion of compulsion or necessity in the following example with the strongly stressed verb to be.

' $\mathrm{X}-\mathrm{I}$ don't intend to allow anyone to see the books.

$\mathrm{Y}-$ But you are going to let us see them for we have the judge's order.'

Nor could it account for the fact that quite frequently the present form of the verb conveys not only a future meaning but also the suggestions of intention, resolve, or determination." Even in Old English we find such an example as the following:

Congreve, The Way of the World, V, 1, 65

'Sir Wilful-Therefore withdraw your instrument, sir, or by'r Lady, $I$ shall draw mine.'

Taylor, The Babes in the Wood, III, 1, 69

'Beetle-There! but let this be a lesson to you, Arabella-the first time you forget it, I shall not return to the Queen's Bench, but I shall certainly apply to Mr. Justice Cresswell.'

"Some examples of this use are the following:

Crothers, He and She

'Keith-Aren't you coming in to see the workroom?'

Pinero, The Second Mrs. Tanqueray, I, 40

'Misquith-I go up to Scotland tomorrow, and there are some little matters. . . .'

Ibid. II, 52.

'Mrs. Cortelton-We go to town this afternoon at five o'clock and sleep tonight at Bayliss's.'

Ibid. II, 45.

'Aubrey-Well, she's going to town, Cayley says here, and his visit's at an end. $H$ e's coming over this morning to call on you. Shall we ask him to transfer himself to us?' 


\section{Alfred, Orosius EETs 1. 42. lines 6, 14, 17, 21}

'Hwa is bxt be eall đa yfel be hi donde wæron asecgean mæ ge ođđe areccan? Eac ic wille gesuigian Tontolis \& Philopes bara scondlicestena spella; bu manega bismerlica gewin Tontolus gefremede syđđan he cyning was; . . . . 'Ic sceall eac forlætan ba be of Perseo \& of Cathma gesæde syndon, . . . .' 'Eac ic wille geswigian para mandæda para Lemniađum \& Ponthionis pæs cyninges, ....'

... . ic hit eall forlæte. Eac ic hit forlæle, Adipsus hu he ægper ofsloh ge his agenne fæder, . . . .'

In this example it seems impossible to take these three expressions as conveying differing shades of meaning. They all three seem to me to suggest with the future the purpose of the speaker - an idea which is in no way related to the primitive meanings of two of the three expressions used.

The suggestion, then, which I should offer as the means of accounting for the facts which we find concerning the expression of the future is this. The grounds upon which the future is usually predicted are desire, hope, intention, resolve, determination, compulsion, necessity, or possibility. Any locutions which express any of these ideas related to the future may be taken up and developed as future tense signs. The course of development is in the direction of their losing their full word meanings and thus also losing their limitation to the particular meanings suggested by their origin. They tend to become future tense signs but with colorings which range from an almost pure future sense to distinctly modal ideas. These colorings are not the glimmerings through of original meanings but may be any one of the grounds upon which the future is predicted, depending upon the context. These colorings are thus the inevitable connotations of the future idea. As such they will attach themselves to any locution developed as a device to express the future so that such a locution may suggest any of the ideas related to the future even if these ideas are wholly unrelated to or opposed to its original full word meaning. This process would thus tend to thwart the developing of any phrase or form into a mere sign of the simple future tense.

(If course in a rapid impression with an entirely unemphasized phrase the general future prediction may be all that registers, yet with more attention put upon the statement, directed by greater emphasis on some part of the word group or by the reader's attempted analysis, there often stand out more prominently some of the connotations of the grounds upon which the future is predicted. 
In a very brief statement the process could be summarized as follows: A certain limited range of ideas furnish the grounds upon which the future is predicted. Any word or form with meanings within this range of ideas may be taken up and used as a device for the expression of future time. As it becomes such a device the emphasis gradually shifts from the full word meaning to the future idea. But now as a device for the expression of the future it may suggest (depending on the circumstances and without limitation of its original meanings) any of that range of ideas which are the bases of future predictions. 